\title{
MANAJEMEN KESISWAAN \\ DALAM MENINGKATAN KUALITAS PESERTA DIDIK MELALUI PROGRAM KARYA TULIS ILMIAH
}

\author{
Bayu Candra Pamungkas, Ilyas Ichsani, Taufiq Subty, Anton \\ Wahyudin \\ UIN Sunan Ampel, Surabaya - Indonesia | bayuchand24@gmail.com
}

\begin{abstract}
Abstrak: Manajemen kesiswaan merupakan seluruh kegiatan pembinaan dan pengembangan peserta didik yang dilaksanakan secara kontinu untuk menumbuhkan bakat, minat, dan kemampuan peserta didik melalui kegiatan kurikuler dan ekstrakulikuler. Program karya tulis ilmiah merupakan salah satu program dalam ranah kesiswaan yang dibuat dan dijalankan untuk melatih dan mengembangkan para peserta didik dalam melaksanakan penelitian dan penulisan suatu karangan ilmiah. Tujuan penelitian ini adalah untuk menjelaskan: (1) Manajemen kesiswaan dalam implementasi program karya tulis ilmiah; (2) kendala yang dihadapi dalam pelaksanaan program karya tulis ilmiah; dan (3) peningkatan kualitas peserta didik dengan adanya program karya tulis ilmiah. Jenis penelitian yang digunakan adalah jenis penelitian lapangan (field research) atau penelitian kualitatif. Sasaran penelitian (subjek penelitian) ini adalah Kepala Madrasah, Wakil Kepala Madrasah Bidang Kesiswaan, dan guru yang menjadi pembimbing dan penguji Karya Tulis IImiah di MA Muhammadiyah 9 Lamongan. Teknik pengumpulan data yang digunakan adalah observasi, wawancara, dan dokumentasi. Teknik analisis data yang digunakan adalah teknik analisis data Miles dan Huberman, yakni reduksi data, penyajian data, dan simpulan. Hasil penelitian menunjukkan bahwa: (1) Manajemen kesiswaan dalam implementasi program karya tulis ilmiah terdiri dari empat tahap, yakni perencaaan, pengorganisasian, pelaksanaan, dan pengendalian program karya tulis ilmiah; (2) kendala yang dihadapi dalam pelaksanaan program karya tulis ilmiah diantaranya adalah faktor siswa, faktor pembimbing, dan faktor fasilitas madrasah; (3) peningkatan kualitas siswa dengan adanya program karya tulis ilmiah dapat dilihat dari pengembangan penalaran peserta didik, terbentuknya mental peserta didik, dan penguasaan teknologi oleh peserta didik.
\end{abstract}


Keywords: manajemen kesiswaan, kualitas peserta didik, karya tulis ilmiah

\section{Pemdahuluan}

Pendidikan merupakan hal yang esensial bagi kehidupan manusia. Pendidikan dapat mengembangkan segala potensi dan bakat terpendam yang dimiliki oleh seseorang. Segala potensi tersebut diharapkan dapat bermanfaat bagi diri pribadi maupun kepentingan orang banyak. Dalam hal ini, pendidikan menjadi faktor pendukung manusia mengatasi segala permasalahan kehidupan baik dalam keluarga, masyarakat, bangsa, dan negara. Pada kenyataannya, pendidikan telah mampu membawa manusia ke arah kehidupan yang lebih beradab. Pendidikan juga merupakan investasi yang paling utama bagi bangsa, apalagi bangsa yang sedang berkembang.

Menurut Imron dalam Hufron, Imron, dan Mustiningsih (2016) manajemen di sekolah: meliputi (a) manajemen pembelajaran; (b) manajemen peserta didik/kesiswaan;

(c) manajemen tenaga kependidikan; (d) manajemen sarana dan prasarana pendidikan;

(e) manajemen keuangan; (f) manajemen kelas; (g) manajemen hubungan sekolah dan masyarakat; dan (h) manajemen layanan khusus pendidikan. Di antara manajemen- manajemen tersebut, manajemen kesiswaan menjadi yang terpenting karena pusat layanan pendidikan di sekolah ada pada peserta didik. Semua kegiatan yang ada di sekolah, baik yang berkenaan dengan manajemen pengajaran, tenaga kependidikan, sarana dan prasarana, keuangan, hubungan sekolah dengan masyarakat maupun layanan khusus pendidikan ditujukan untuk memberikan pelayanan terbaik bagi para peserta didik.

Manajemen kesiswaan merupakan penggabungan dari kata manajemen dan kesiswaan. Secara etimologis, kata manajemen berasal dari bahasa Italia maneggiare yang berarti melatih kuda agar dapat melangkah dan menari seperti yang dikehendaki pelatihnya. Kata manajemen merupakan terjemahan dari management yang berarti pengelolaan. Dalam bahasa Indonesia, 
manajemen dapat diartikan mengendalikan, menangani atau mengelola. Hal ini senada dengan yang diungkapkan Yayat M. Herujito (2001) bahwa manajemen adalah pengelolaan, pengendalian atau penanganan suatu hal dalam mencapai suatu tujuan tertentu.

Sedangkan kata kesiswaan berasal dari kata dasar siswa. Siswa mempunyai banyak padanan kata, diantaranya pembelajar, murid, santri, peserta didik. Peserta didik sendiri diartikan sebagai anggota masyarakat yang berusaha mengembangkan potensi diri melalui proses pembelajaran yang tersedia pada jalur, jenjang, dan jenis pendidikan tertentu (Undang-undang RI No. 20 tahun 2003 tentang Sistem Pendidikan Nasional). Siswa adalah sekelompok orang atau individu yang mengembangkan potensi yang dimilikinya dan mendapatkan pelayanan sesuai dengan bakat dan minat serta kemampuannya agar dapat tumbuh secara optimal (Muhammad Miftah, 2017).

Manajemen siswa bukan hanya berbentuk pencatatan peserta didik, melainkan meliputi aspek yang lebih luas yang secara operasional dapat membantu upaya pertumbuhan dan perkembangan peserta didik melalui proses pendidikan disekolah (Abdul Rahman Saleh, 2001). Dari situ memberikan gambaran bahwa manajemen kesiswaan bukan hanya sekadar pencatatanpencatatan semata, namun meliputi segala aspek yang berkaitan dengan aktifitas peserta didik mulai dari perencanaan sampai dengan evaluasi.

Mulyono dalam Kurniawati dan Roesminingsih (2014) mengemukakan bahwa manajemen kesiswaan adalah seluruh proses kegiatan yang direncanakan dan diusahakan secara sengaja serta pembinaan secara kontinu terhadap seluruh peserta didik agar dapat mengikuti proses belajar mengajar secara efektif dan efisien. Manajemen kesiswaan juga berarti melakukan pembinaan dan pengembangan terhadap peserta didik. Pembinaan dan pengembangan peserta didik dilakukan agar peserta didik mendapat bermacam- macam pengalaman belajar untuk bekal kehidupannya di masa yang akan datang. Untuk mendapatkan pengetahuan atau pengalaman belajar ini, peserta didik harus 
melakukan bermacam-macam kegiatan (Kurniawati dan Roesminingsih, 2014).

Dalam kegiatan pembinaan dan pengembangan inilah siswa atau peserta didik diproses untuk menjadi manusia yang diharapkan sesuai dengan tujuan pendidikan. Bakat, minat dan kemampuan peserta didik harus ditumbuhkembangkan secara optimal melalui kegiatan kurikuler dan ekstrakurikuler. Dalam manajemen kesiswaan, tidak boleh ada anggapan bahwa kegiatan kurikuler lebih penting dari kegiatan ekstrakurikuler atau sebaliknya. Kedua kegiatan ini harus dilaksanakan karena saling menunjang dalam proses pembinaan dan pengembangan kemampuan peserta didik.

Sehingga manajemen kesiswaan dapat diartikan sebagai seluruh kegiatan pembinaan dan pengembangan peserta didik yang dilaksanakan secara kontinu untuk menumbuhkan bakat, minat, dan kemampuan siswa melalui kegiatan kurikuler dan ekstrakulikuler. Ada bermacam-macam kegiatan yang dapat dilaksanakan untuk mengembangkan kemampuan siswa, salah satunya adalah melalui kegiatan karya tulis ilmiah. Kegiatan pembuatan karya tulis ilmiah dinilai mampu memberikan banyak dampak positif terhadap perkembangan siswa.

Robert Day (1979) berpendapat bahwa "a scientific paper is a written report describing original research results whose format has been defined by centuries of developing tradition, editorial practice, scientific ethics and the interplay with printing and publishing services." Artinya bahwa karya ilmiah adalah laporan tertulis yang menggambarkan hasil penelitian asli yang formatnya telah ditentukan. Dinamakan karya tulis ilmiah karena merupakan suatu hasil penelitian yang dilakukan secara ilmiah.

Karya ilmiah merupakan satu karangan yang disusun secara sistematis dan bersifat ilmiah (Abdullah, 2016). Sistematis berarti bahwa karya tulis tersebut disusun menurut aturan tertentu sehingga kaitan antara bagian-bagian tersebut jelas dan padu. Bersifat ilmiah berarti bahwa karya tulis tersebut menyajikan satu deskripsi gagasan, argumentasi, atau pemecahan masalah yang didasarkan pada berbagai bukti empirik atau kajian teoritis. 
Brotowijoyo dalam Arifin (1993) juga menyebutkan bahwa karangan ilmiah adalah karangan ilmu pengetahuan yang menyajikan fakta dan ditulis menurut metodologi penulisan yang baik dan benar.

Program karya tulis ilmiah adalah program yang dibuat dan dijalankan untuk melatih dan mengembangkan para peserta didik dalam melaksanakan penelitian dan penulisan suatu karangan ilmiah. Penelitian ini penting untuk mengetahui implementasi program karya tulis ilmiah terhadap perkembangan kemampuan peserta didik. Banyak penelitian terdahulu yang membahas tentang manajemen kesiswaan, namun tidak banyak yang membahas khusus tentang kegiatan karya tulis ilmiah. Oleh karena itu, peneliti ingin mengetahui implementasi program karya tulis ilmiah dalam meningkatkan kualitas siswa. Maka peneliti mengambil judul Manajemen Kesiswaan dalam Meningkatkan Kualitas Peserta Didik Melalui Program Karya Tulis Ilmiah.

Tujuan penelitian ini adalah untuk mengetahui berbagai hal mengenai program karya tulis ilmiah yang merupakan bagian dari manajemen kesiswaan di MA Muhammadiyah 9 Lamongan. Fokus penelitian diantaranya adalah sebagai berikut: (1) Manajemen kesiswaan dalam implementasi program karya tulis ilmiah; (2) kendala yang dihadapi dalam pelaksanaan program karya tulis ilmiah; dan (3) peningkatan kualitas siswa dengan adanya program karya tulis ilmiah.

\section{Metodologi}

Penelitian ini dilaksanakan pada 19 Agustus hingga 17 September 2019 di Madrasah Aliyah Muhammadiyah 9 Lamongan yang berlokasi di Jl. Jenderal Sudirman No. 1 Lamongan. Jenis penelitian yang digunakan adalah jenis penelitian lapangan (field research) atau penelitian kualitatif. Sasaran penelitian (subjek penelitian) ini adalah Kepala Madrasah, Wakil Kepala Madrasah Bidang Kesiswaan, dan guru yang menjadi pembimbing dan penguji Karya Tulis Ilmiah di MA Muhammadiyah 9 Lamongan. Dalam penelitian kualitatif, yang menjadi instrumen atau alat penelitian adalah peneliti. Validasi terhadap peneliti sebagai instrumen adalah meliputi validasi terhadap pemahaman metode 
penelitian kualitatif, penguasaan wawasan terhadap bidang yang diteliti, dan kesiapan peneliti. Teknik pengumpulan data yang digunakan adalah observasi, wawancara, dan dokumentasi. Observasi merupakan teknik pengumpulan data dengan pengamatan langsung (Faisal, 1995). Metode wawancara adalah pengumpulan data dengan cara tanya jawab secara sepihak yang dikerjakan secara sistematis dengan landasan tujuan penelitian (Hadi, 1991). Sedangkan dokumentasi adalah metode pengumpulan data berupa dokumen (Bungin, 2001). Data yang diperlukan dalam penelitian ini adalah data yang memberikan informasi tentang manajemen kesiswaan khususnya dalam program karya tulis ilmiah (paper) di madrasah. Teknik analisis data yang digunakan adalah teknik analisis data Miles dan Huberman. Analisis data merupakan upaya mencari dan menata secara sistematis catatan hasil observasi, wawancara, dan studi dokumen untuk meningkatkan pemahaman peneliti tentang kasus yang diteliti (Arikunto, 1998). Aktivitas dalam analisis data pada penelitian ini adalah reduksi data, penyajian data, dan simpulan.

\section{Hasil dan Pembahasan}

MA Muhammadiyah 9 Lamongan memiliki berbagai kegiatan penunjang untuk mengoptimalkan kualitas para peserta didik. Diantara kegiatan penunjang yang ada, program Karya Tulis Ilmiah (KTI) merupakan program unggulan yang dikembangkan di madrasah ini. Para pendidik dan siswa MA Muhammadiyah 9 Lamongan menyebut program Karya Tulis Ilmiah ini sebagai paper. Paper pertama kali dilaksanakan pada tahun 2004. Program paper ini diinisiasi oleh pondok pesantren. Namun, seiring berjalannya waktu, tanggungjawab pelaksanaan program ini diberikan kepada madrasah. Sejarah adanya paper bermula dari adanya kekosongan kegiatan para peserta didik kelas XII setelah melaksanakan Ujian Nasional (UN). Sehingga perlu menghadirkan kegiatan penunjang yang bermanfaat bagi siswa untuk mengisi kekosongan waktu tersebut.

Seiring dengan berjalannya waktu, program Karya Tulis Ilmiah/paper ini semakin berkembang dan terus mengalami perbaikan dalam pelaksanaannya. Hal ini dibuktikan dengan 
disusunnya pedoman Karya Tulis Ilmiah (KTI) bagi para peserta didik dan pendidik pada tahun 2015. Pedoman Karya tulis ilmiah ini disusun oleh tiga guru senior di bidang kepenulisan, yakni Ibu Mei Runa Eka Wati, S.Pd selaku guru Bahasa Indonesia, Ibu Zusi Purwanti, S.E yang merupakan Wakil Kepala Madrasah bidang Kurikulum, dan Pak Suwito. Pedoman ini sangat bermanfaat untuk menyamakan pandangan para siswa dalam tata cara penulisan paper dan guru yang menjadi pembimbing maupun penguji dalam memberikan bimbingan dan penilaian paper.

Penanggung jawab program Karya Tulis Ilmiah (KTI)/ paper ini adalah Wakil Kepala Madrasah bidang Kesiswaan. Waka Kesiswaan juga merupakan editor pedoman paper. Pada tahun pelajaran 2018/2019 ini program Karya Tulis Ilmiah mulai mengalami proses transisi. Jika sebelumnya paper dilaksanakan oleh kelas XII, maka pada tahun pelajaran ini program ini mulai diterapkan pada kelas XI. Hal ini mempertimbangkan kesibukan kelas XII yang harus fokus pada ujian kelulusan, termasuk Ujian Nasional (UN) dan program PDL (Praktik Dakwah Lapangan).

Rangkaian proses program Karya Tulis Ilmiah (KTI) dilaksanakan dalam waktu 7-

9 bulan. Berdasarkan temuan penelitian di MA Muhammadiyah 9 Lamongan menunjukkan bahwa tahapan implementasi program Karya Tulis Ilmiah (KTI)/ paper adalah sebagai berikut: (1) Perencaaan program karya tulis ilmiah; (2) pengorganisasian program karya tulis ilmiah; (3) pelaksanaan program karya tulis ilmiah; dan (4) pengendalian program karya tulis ilmiah. Seluruh tahapan proses tersebut masing-masing dapat diuraikan ke bagianbagian yang lebih rinci lagi.

Pertama, perencaaan program karya tulis ilmiah. Perencanaan program KTI dimulai dari agenda RAKER (Rapat Kerja) Madrasah yang menentukan program dan kegiatan yang akan dijalankan selama satu tahun ajaran. Adapun program KTI merupakan salah satu program rutin setiap tahun secara konsisten diselenggarakan MA Muhammadiyah 9 Lamongan. Program ini merupakan salah satu program yang dijalankan madrasah melalui Waka kesiswaan. 
Berikutnya adalah perencanaan pembiayaan. Pembiayaan program KTI ini telah melewati beberapa tahap. Pada awalnya pembiayaan ditanggung penuh oleh madrasah, namun seiring berjalannya waktu akhirnya disepakati bahwa pembiayaan program KTI di bebankan kepada siswa yang dimasukkan dalam rincian biaya daftar ulang masuk madrasah. Biaya ini nantinya akan diolah untuk memenuhi segala kebutuhan terkait pelaksanaan program KTI.

Kemudian juga perencanaan dalam hal waktu (timeline). Timeline pengajuan judul, waktu bimbingan, hingga sidang paper juga dirumuskan dengan baik menyesuaikan jadwal lain pada tahun ajaran tersebut. Penanggung jawab sekaligus pembuat perencanaan ini adalah Waka Kesiswaan yang juga sekaligus Ketua Program Karya Tulis Ilmiah. Pada tahun ini karena terdapat transisi, maka jadwal disosialiasikan kepada seluruh peserta didik kelas XI dan XII pada awal tahun ajaran baru. Jadwal ditempel di mading dan dinding yang mudah dijangkau oleh siswa sehingga informasi mengenai timeline program KTI ini dapat tersampaikan dengan baik.

Jadi, dapat disimpulkan bahwa tahapan dalam perencanaan program Karya tulis ilmiah ini setidaknya ada tiga hal, diantaranya adalah perencanaan dan pemberian tanggung jawab program dalam RAKER (Rapat Kerja) Madrasah, perencanaan pembiayaan melalui daftar ulang, dan perencanaan jadwal (timeline) program KTI. Perencanaan yang baik adalah langkah awal berhasilnya pelaksanaan suatu program.

Kedua, pengorganisasian program karya tulis ilmiah. Pengorganisasian meliputi dua hal, yakni pengorganisasian panitia penanggung jawab program serta pengorganisasian pembimbing dan penguji. Panitia penanggung jawab program KTI diketuai oleh Waka Kesiswaan yang beranggotakan para pimpinan sebagai panitia kecil, seperti waka humas, waka sarana prasarana, waka kurikulum, dan bendahara. Hal ini karena tugas yang tidak terlalu berat, hanya pada pelaksanaan sidang paper yang agak membutuhkan kerjasama secara teknis. Panitia kecil ini juga 
diberikan SK (Surat Keputusan) dari Kepala Madrasah sehingga bertanggung jawab secara penuh atas kelancaran program ini.

Pengorganisasian pembimbing dan penguji melihat beberapa hal. Tidak semua guru menjadi pembimbing atau penguji. Ada kriteria tertentu dalam pemilihan guru sehingga dapat ditunjuk menjadi pembimbing maupun penguji. Diantaranya adalah status guru, artinya yang dipilih adalah para guru tetap yang memiliki tugas utama di MA Muhammadiyah 9 Lamongan dengan masa mengajar paling sedikit dua tahun. Ada 22 dari 45 guru yang dilibatkan sebagai pembimbing dan penguji pada program KTI ini. Setiap satu siswa akan mendapat bimbingan dari dua orang pembimbing yang memiliki kompetensi di bidang permasalahan yang diangkat oleh peserta didik. Pembimbing I nantinya akan berfokus pada isi atau substansi permasalahan yang diangkat, sedangkan pembimbing II akan berfokus pada kepenulisan KTI sesuai pedoman yang telah dibuat.

Ketiga, pelaksanaan program karya tulis ilmiah. Pelaksanaan KTI sendiri terdapat beberapa tahap yang dimulai dari: (1) Peserta didik mencari isu/masalah (judul paper);

(2) pemilihan pembimbing sesuai masalah; (3) kuliah umum (sosialisasi pedoman KTI);

(4) bimbingan siswa ke pembimbing; (5) pengumpulan paper; (6) sidang paper; (7) revisi paper dengan bimbingan penguji; dan (8) pengumpulan revisi paper. Keseluruhan proses pelaksanaan program KTI ini dapat dijelaskan sebagai berikut.

Pencarian dan penggalian isu oleh peserta didik merupakan tahap awal yang dilaksanakan untuk kemudian mendapatkan judul paper yang akan diteliti. Pada tahap ini peserta didik diberikan kesempatan untuk mengeksplorasi berbagai hal sesuai minatnya. Bidang pembahasan KTI diantaranya adalah tentang pendidikan, hukum, aqidah, dan ilmu pengetahuan (Wati, 2018). Bidang-bidang tersebut ditentukan karena merupakan bidang yang memungkinkan untuk diteliti. Berikutnya setelah peserta didik telah mendapatkan topik penelitian, maka akan dilakukan pembagian pembimbing. Masing-masing pembimbing akan bertanggung jawab membimbing 8-9 peserta didik. Jumlah tersebut 
ditentukan dengan harapan pembimbing dapat memberikan bimbingan optimal kepada para peserta didik. Selain itu, para pembimbing akan dibagi sesuai bidang kajian atau topik yang telah ada. Tentunya disesuaikan dengan kompetensi masing-masing pembimbing

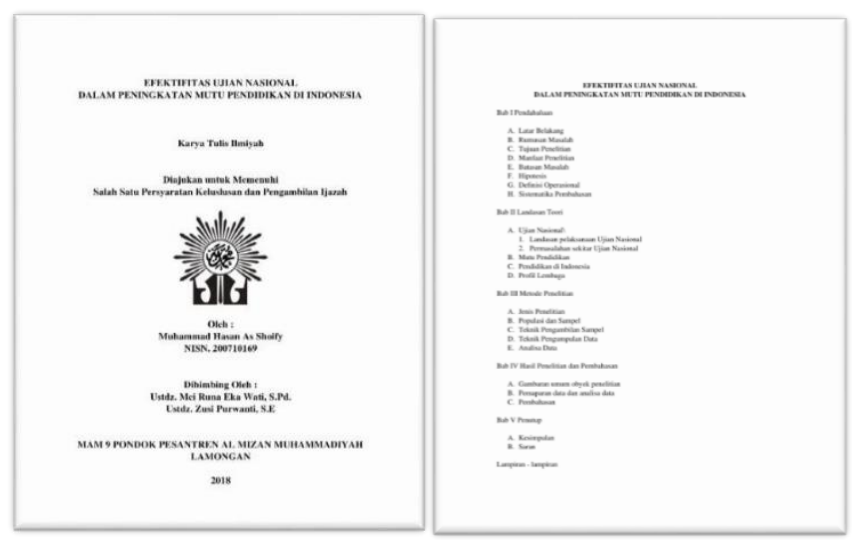

Gambar 1 dan 2:

Cover dan Sistematika Penulisan Karya Tulis Ilmiah di Buku Pedoman (Wati, 2018)

Selanjutnya diadakan kuliah umum yang berupa sosialisasi dan penyampaian tentang pedoman KTI. Kuliah umum ini disampaikan untuk memberikan pemahaman kepada peserta didik tentang sistematika KTI yang akan disusun. Sosialisasi ini disampaikan oleh Ibu Mei Runa Eka Wati, S.Pd yang merupakan salah satu penyusun pedoman KTI. Sosialisasi yang dilaksanakan dalam sehari tersebut dirasa sangat kurang untuk memamahamkan peserta didik mengenai teknis penulisan penyusunan karya tulis ilmiah. Sehingga, beliau sebagai guru bahasa Indonesia berinisiatif untuk menyampaikan penekanan materi tentang karya tulis kepada para peserta didik pada KBM (Kegiatan Belajar Mengajar) di kelas.

Setelah itu, hal teknis selanjutnya langsung diarahkan ke guru pembimbing masing- masing. Para peserta didik dapat melakukan bimbingan di luar jam aktif KBM (Kegiatan Belajar Mengajar). 
Waktu bimbingan kurang lebih tiga bulan untuk bab I-III dan tiga bulan untuk bab IV-V. Enam bulan waktu bimbingan diharapkan dapat menghasilkan karya tulis ilmiah yang baik. Para pembimbing dengan sabar senantiasa membimbing peserta didik dalam penulisan karya tulis ilmiah hingga terselesaikan.

Setelah para peserta didik selesai melaksanakan penelitian dan bimbingan, hasil karya tulisnya kemudian dikumpulkan di ruang tata usaha madrasah. Untuk hasil paper peserta didik dikumpulkan ke Ustadz Rohid dan Ustadzah Umi. Hasil tersebut sebelumnya harus sudah mendapatkan persetujuan dari kedua pembimbing. Paper yang telah dikumpulkan para peserta didik tersebut kemudian didistribusikan ke para penguji. Setelah sekitar satu minggu pasca pengumpulan, maka akan dilaksanakan sidang paper untuk mempertanggungjawabkan karya tulis ilmiah yang telah dibuat oleh peserta didik.

Pelaksanaan sidang paper dilaksanakan dua hari. Ada sebelas ruang yang disiapkan untuk melaksanakan sidang KTI, dimana setiap ruang terdapat dua orang penguji. Pelaksanaan sidang dimulai dari pemanggilan peserta sidang, presentasi peserta, pengajuan pertanyaan dan pemberian masukan dari penguji, jawaban dan tanggapan peserta, dan ditutup dengan penentuan kelulusan peserta oleh penguji. Sidang KTI ini menguji substansi paper dan melihat kesesuaian sistematika kepenulisan yang digunakan. Adapaun pembahasan dan pertanyaan yang diajukan oleh penguji mulai dari judul, latar belakang, rumusan masalah, metode penelitian, hasil dan pembahasan, kesimpulan, hingga referensi. 


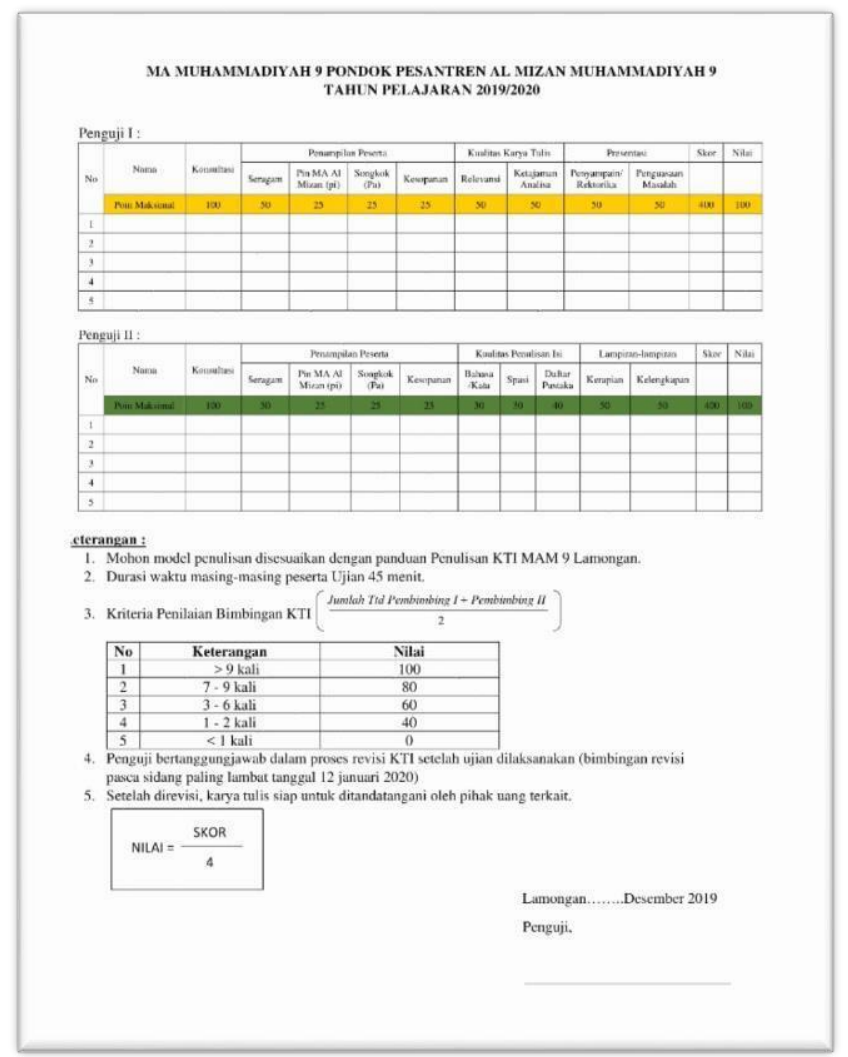

Gambar 3: Format Penilaian Sidang KTI (Wahyudin, 2019)

Selanjutnya jika dinyatakan lulus dengan revisi, maka peserta didik tersebut harus memperbaiki hasil paper nya sesuai catatan yang diberikan oleh penguji. Selain itu, tanggungjawab memberikan bimbingan dialihkan dari pembimbing ke penguji, sehingga peserta didik harus melaksanakan bimbingan ke penguji untuk menyempurnakan hasil paper revisi yang akan dibuat. Waktu yang diberikan untuk merevisi paper adalah dua hingga tiga minggu. Kemudian, paper hasil revisi tersebut di cetak menggunakan hardcover dan dikumpulkan di ruang tata usaha. Selanjutnya, hasil karya peserta didik tersebut akan diserahkan ke perpustakaan madrasah untuk diarsip. 
Keempat, pengendalian program karya tulis ilmiah. Terdapat dua hal yang menjadi alat monitoring dalam program ini. Kedua hal tersebut adalah adanya kartu bimbingan untuk siswa dan diadakannya forum sharing pembimbing. Kartu bimbingan tersebut dapat mengetahui intensitas siswa melakukan bimbingan ke pembimbing dan mengetahui sejauh mana progress KTI peserta didik. Kartu bimbingan telah disediakan oleh pihak madrasah. Setiap kali melaksanakan bimbingan, peserta didik harus menuliskan tanggal bimbingan, mendapatkan tanda tangan pembimbing, serta menuliskan keterangan progress karyanya.

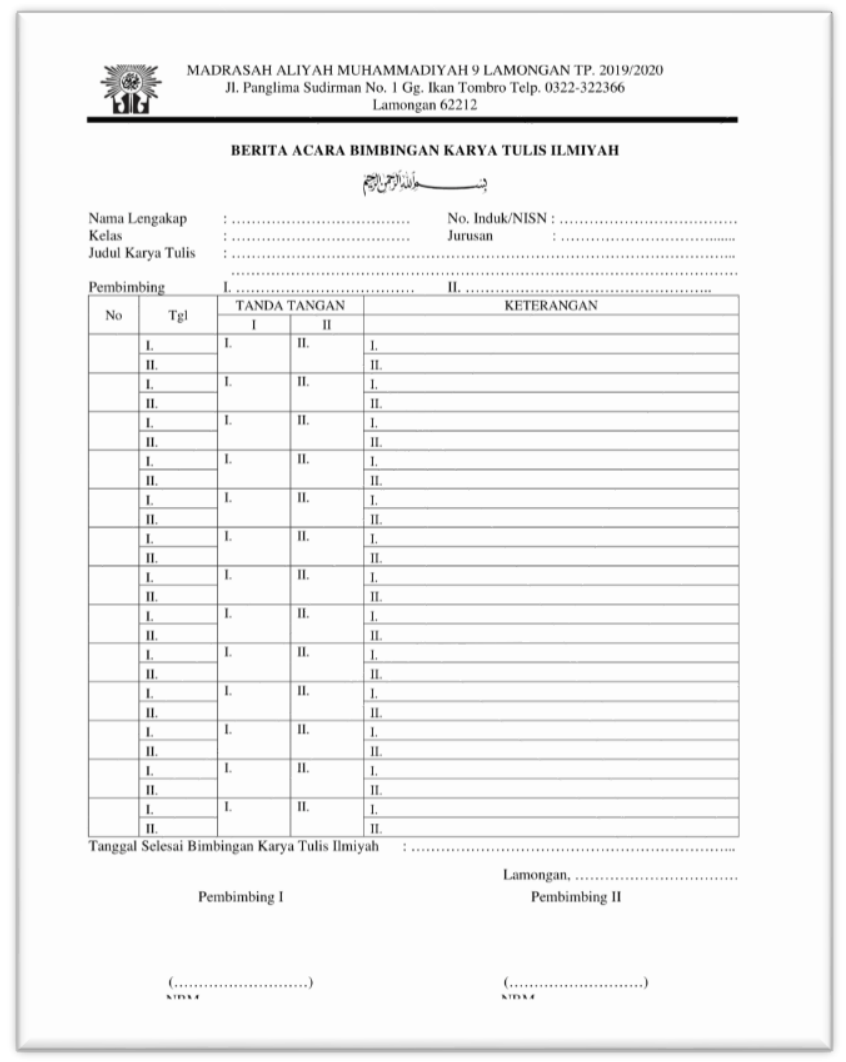

Gambar 4: Kartu Bimbingan Karya Tulis Ilmiah 
Selain kartu bimbingan, dalam melakukan pengendalian program KTI ini juga diadakan forum sharing pembimbing yang dilaksanakan secara insidental. Artinya forum sharing ini diagendakan hanya pada waktu tertentu saja, tidak secara rutin. Forum ini akan dilaksanakan saat muncul masalah di lapangan. Tujuan adanya forum ini adalah untuk menyamakan persepsi para pembimbing dan menyelesaikan masalah yang muncul dari program KTI ini. Sehingga fungsi controlling dalam pelaksanaan program ini dapat berjalan dengan baik dan program ini dapat berjalan dengan lancar.

Karakteristik pelaksanaan program karya tulis ilmiah dalam penelitian ini, pada dasarnya sesuai dengan pendapat George R. Terry dalam bukunya Principles of Management (Sukarna, 2011) yang membagi empat fungsi dasar manajemen, yaitu planning (perencanaan), organizing (pengorganisasian), actuating (pelaksanaan), dan controlling (pengawasan). Keempat fungsi manajemen ini disingkat dengan POAC.

Pada pelaksanaan program apapun pasti terdapat kendalakendala yang ditemui. Begitu pula dengan pelaksanaan program karya tulis ilmiah di MA Muhammadiyah 9 Lamongan. Kendala merupakan faktor atau keadaan yang membatasi, menghalangi, atau mencegah pencapaian tujuan. Berdasarkan temuan penelitian di MA Muhammadiyah 9 Lamongan ditemukan sejumlah kendala yang berkaitan dengan program KTI yang dijalankan, diantaranya adalah faktor peserta didik, faktor pembimbing, faktor fasilitas madrasah.

Pertama, kendala faktor peserta didik. Setiap peserta didik memiliki kemampuan yang berbeda- beda. Sebagian besar peserta didik merasa terbebani dengan adanya program karya tulis ilmiah ini. Bahkan, para peserta didik menilai tugas paper atau karya tulis ilmiah ini lebih berat dibandingkan dengan UN (Ujian Nasional). Hal ini membuat beberapa peserta didik yang kebingungan akhirnya menunda-nunda pengerjaan KTI, sehingga hasilnya tidak maksimal. Dampaknya saat sidang paper banyak peserta didik yang harus melakukan revisi atas karyanya, bahkan ada yang harus melaksanakan sidang ulang. Yang paling fatal bahkan pernah ada 
satu peserta didik yang tidak membuat paper sama sekali. Tentu hal ini merupakan kendala yang harus dicarikan solusinya agar peserta didik memahami begitu pentingnya program ini untuk meningkatkan kemampuan mereka.

Kedua, kendala faktor pembimbing. Ada beberapa hal yang membuat kurang maksimalnya peran pembimbing dalam membimbing peserta didik. Diantaranya adalah masalah waktu. Intensitas kehadiran pembimbing ke madrasah, jadwal mengajar yang padat, hingga melaksanakan tanggungjawab manajerial tambahan lainnya juga menjadi alasan kurangnya waktu pembimbing untuk memberikan bimbingannya kepada peserta didik. Peserta didik dan para pembimbing harus mengatur waktu sedemikian rupa untuk dapat melaksanakan bimbingan KTI. Waktu yang sering digunakan para peserta didik untuk konsultasi ke pembimbingnya adalah saat istirahat dan jam pulang sekolah. Para siswa harus mengoptimalkan waktu yang ada di sela-sela kegiatan belajar mengajar yang ada di madrasah.

Ketiga, kendala fasilitas madrasah. Fasilitas merupakan salah satu hal penting yang harus dipenuhi madrasah untuk menunjang segala kegiatan-kegiatannya. Fasilitas utama yang dibutuhkan dalam pelaksanaan program KTI ini adalah komputer. Madrasah hanya memiliki dua laboratorium komputer dimana masing-masing terdapat 25 dan 35 komputer. Sehingga ada 60 komputer yang dapat digunakan para siswa secara bergantian untuk mengerjakan KTI. Jumlah ini tentu masih belum dapat memfasilitasi peserta didik secara keseluruhan. Namun, kendala ini mendapatkan solusi dimana di asrama putri terdapat fasilitas komputer, sedangkan putra diperbolehkan menggunakan laptop namun penggunanaannya dibatasi waktu. Pembatasan-pembatasan ini tentu menjadi salah satu kurang optimalnya hasil paper para peserta didik.

Peningkatan kualitas peserta didik merupakan tujuan dari terselenggaranya program karya tulis ilmiah ini. Kualitas peserta didik dapat diukur dari berbagai faktor. Berdasarkan temuan penelitian di MA Muhammadiyah 9 Lamongan ada beberapa hal yang menunjukkan peningkatan kualitas peserta didik, diantaranya 
adalah pengembangan penalaran, terbentuknya mental, dan penguasaan teknologi oleh peserta didik.

Pertama, adanya pengembangan penalaran peserta didik. Hampir seluruh peserta didik yang telah menjadi alumni bersyukur atas adanya program KTI ini. Hal ini diungkapkan karena mereka merasa program tersebut membawa dampak positif bagi mereka, terlebih yang melanjutkan pendidikan ke perguruan tinggi. Pengerjaan paper telah membuat mereka terbiasa berpikir ilmiah dan sistematis serta meningkatkan kemampuan literasi mereka. Para guru yang menjadi pembimbing juga melihat progress yang baik terhadap penalaran peserta didik yang telah menyelesaikan karya tulisnya.

Kedua, terbentuknya mental peserta didik. Mental peserta didik yang dimaksud adalah yang berkaitan dengan sikap para peserta didik. Program ini membuat para peserta didik harus melakukan konsultasi atau bimbingan dengan para pembimbing. Hal tersebut secara tidak langsung melatih keberanian peserta didik untuk menemui guru yang menjadi pembimbingnya. Selain itu, para peserta didik juga belajar melakukan komunikasi dengan adab yang baik ketika melakukan konsultasi dengan pembimbing. Intensitas pertemuan bimbingan juga telah meningkatkan kedekatan antara peserta didik dengan para guru. Keseluruhan faktor tersebut pada akhirnya mampu membentuk mental positif pada diri siswa.

Ketiga, penguasaan teknologi oleh peserta didik. Penguasaan teknologi yang dimaksud adalah yang berkenaan dengan penggunaan komputer sebagai salah satu sarana atau alat teknologi. Penyusunan karya tulis ilmiah tentu membutuhkan kemampuan untuk mengetik menuangkan gagasan ke dalam tulisan menggunakan komputer. Fakta menyebutkan bahwa tidak semua peserta didik MA Muhammadiyah 9 Lamongan memiliki kemampuan mengetik dan mengoperasikan komputer dengan baik. Adanya program KTI ini ternyata juga turut meningkatkan kualitas peserta didik pada bidang teknologi, khususnya dalam mengoperasikan komputer dan melakukan pengetikan untuk menyusun karya tulisnya. 


\section{Kesimpulan}

Dari uraian tentang pembahasan dan hasil temuan penelitian, maka dapat disimpulkan sebagai berikut:

Manajemen kesiswaan dalam implementasi program karya tulis ilmiah terdiri dari empat tahap, yakni: (1) Perencaaan program karya tulis ilmiah, meliputi pembahasan program saat RAKER (Rapat Kerja) madrasah, perencanaan pembiayaan, dan perencanaan waktu; (2) pengorganisasian program karya tulis ilmiah, meliputi pengorganisasian panitia penanggung jawab program serta pengorganisasian pembimbing dan penguji; (3) pelaksanaan program karya tulis ilmiah, meliputi beberapa tahap yang dimulai dari siswa mencari isu/masalah (judul paper), pemilihan pembimbing sesuai masalah, kuliah umum (sosialisasi pedoman KTI), bimbingan peserta didik ke pembimbing, pengumpulan paper, sidang paper, revisi paper dengan bimbingan penguji, dan pengumpulan revisi paper; dan (4) pengendalian program karya tulis ilmiah, meliputi adanya kartu bimbingan untuk siswa dan diadakannya forum sharing pembimbing.

Kendala yang dihadapi dalam pelaksanaan program karya tulis ilmiah diantaranya adalah (1) faktor peserta didik, meliputi peserta didik merasa terbebani, penundaan pengerjaan KTI, hingga ada yang pernah tidak membuat KTI; (2) faktor pembimbing, meliputi intensitas kehadiran guru pembimbing, kendala waktu akibat kesibukan mengajar dan tanggungjawab tambahan yang diberikan madrasah; dan (3) faktor fasilitas madrasah, meliputi keterbatasan jumlah komputer yang dimiliki madrasah.

Peningkatan kualitas peserta didik dengan adanya program karya tulis ilmiah dapat dilihat dari (1) pengembangan penalaran peserta didik, yang meliputi kemampuan berpikir ilmiah, sistematis, dan literasi; (2) terbentuknya mental peserta didik, yang meliputi keberanian untuk berkomunikasi dengan guru pembimbing serta terbentuknya sikap atau adab yang baik; (3) penguasaan teknologi oleh peserta didik, berupa kemampuan mengoperasikan komputer dengan baik, khususnya dalam mengetik. 
Berdasarkan paparan pembahasan, hasil penelitian, dan simpulan, beberapa sarana yang direkomendasikan pada pihakpihak terkait yaitu:

Kepala MA Muhammadiyah 9 Lamongan sebagai manajer dan pimpinan madrasah yang bertanggungjawab atas kualitas peserta didik diharapkan melakukan pengembangan di bidang manajemen kesiswaan. Sehingga madrasah tetap eksis dalam melaksanakan pendidikan dengan karya tulis ilmiah yang menjadi program unggulan. Program ini harus berkembang misalnya dengan mengikutkan para peserta didik ke ajang perlombaan karya tulis ilmiah baik tingkat kabupaten, provinsi, maupun nasional.

Wakil Kepala Madrasah bidang kesiswaan MA Muhammadiyah 9 Lamongan hendaknya selalu melakukan inovasi-inovasi ke arah perbaikan dalam pengelolaan kesiswaan khususnya dalam melaksanakan program karya tulis ilmiah. Program ini harus mendapat perhatian yang besar agar dapat menjadi role model untuk kegiatan atau program kesiswaan lainnya.

Guru MA Muhammadiyah 9 Lamongan khususnya yang menjadi pembimbing karya tulis ilmiah para peserta didik hendaknya dapat menjadi teladan. Para guru harus memiliki niat tulus, ikhlas, dan memberikan keramahan dalam membimbing para peserta didik sehingga dapat memberikan manfaat optimal terhadap kualitas peserta didik.

Para peserta didik MA Muhammadiyah 9 Lamongan yang mengerjakan paper/ karya tulis ilmiah hendaknya selalu bersemangat dan berpikiran optimis. Percaya bahwa akan ada banyak hal positif yang akan didapat dalam proses pengerjaan karya tulis ilmiah ini. Man yazra' yahsud, siapa yang menanam akan menuai hasilnya. Proses yang baik akan memberikan hasil yang baik di masa depan.

Peneliti lain, semoga penelitian ini dapat dijadikan bahan referensi dan informasi untuk mengembangkan dan melaksanakan penelitian sejenis dalam bidang manajemen kesiswaan, sehingga dapat menambah wawasan tentang keilmuan manajemen pendidikan, khususnya tentang manajemen kesiswaan. 


\section{References}

Abdullah, A. A., Alfin, J., Udin, N.H.W., dan Adhitama, T. S. (2016). Teknik Penulisan Karya Ilmiah. Surabaya: UIN Sunan Ampel Press.

Arifin, E.Z. (1993). Penulisan Karangan Karya Ilmiah Dengan Bahasa Indonesia Yang Benar (Pedoman Praktisi Untuk Perguruan Tinggi). Jakarta: Media Atamasarana Perkasa.

Arikunto, S. (1998). Prosedur Penelitian: Suatu Pendekatan Praktek, Cet. XI. Jakarta: Rineka Cipta.

Bungin, B. (2001). Metodologi Penelitian Sosial: Format-format Penelitian Kuantitatif dan Kualitatif. Surabaya: Airlangga University Press.

Day, R. (1979). How to Write and Publish a Scientific Paper. Philadelphia: ISI Press. Faisal, S. (1995). Format-format Penelitian Sosial: Dasar-dasar dan Aplikasi. Jakarta:

Raja Grafindo Persada.

Hadi, S. (1991). Metodologi Research. Yogyakarta: Andi Offset. Herujito, Y. M. (2001) Dasar-dasar Manajemen. Jakarta: Grasindo.

Hufron, A., Imron, A., \& Mustiningsih. (2016). Manajemen Kesiswaan Pada Sekolah Inklusi. Jurnal Pendidikan Humaniora, 4 (2), 95-105.

Kurniawati, E., Roesminingsih, E. (2014). Manajemen Kesiswaan di SMA Negeri Mojoagung Jombang. Jurnal Inspirasi Manajemen Pendidikan, 4 (4), 207-213.

Miftah, M. (2017). Reaktualisasi Manajemen Kesiswaan dalam Mempertahankan Local Wisdom (Studi Analisis di MTs Miftahul Ulum Karangmojo, Klego, Boyolali). Jurnal Penelitian, 11 (2), 237-254.

Saleh, A. R. (2001). Madrasah dan Pendidikan Anak Bangsa: Visi, Misi, dan Aksi.

Jakarta: Raja Grafindo Persada. 
Sukarna. (2011). Dasar-Dasar Manajemen. Bandung: Mandar Maju. Undang-undang RI No. 20 tahun 2003 tentang Sistem Pendidikan Nasional

Wahyudin, A. (2019). Laporan Kegiatan Karya Tulis Ilmiah (KTI) Siswa Kelas XII MA Muhammadiyah 9 Lamongan. Lamongan: MA Muhammadiyah 9 Lamongan.

Wati, M.R.E., Purwanti, Z., dan Suwito. (2018). Pedoman Penulisan Karya Tulis Ilmiah MA Muhammadiyah 9 Lamongan, Edisi Revisi II. Lamongan: Fan Amru Press. 